\title{
On Sea Monsters and Sandcastles
}

\section{Revisiting International Legal Frameworks regarding Public Health and Human Rights in Global Health Emergencies}

\author{
Alicia Ely Yamin, ${ }^{*}$ Stefania Negri** and Roojin Habibi***
}

\section{Introduction}

As a new coronavirus, SARS-CoV-2, swept across the globe with unprecedented speed in 2020 , countries were faced with navigating between the proverbial Scylla and Charybdis. In a quickly evolving situation, with limited and constantly changing scientific information, governments across varied income levels adopted an array of strategies across a spectrum of divergent approaches. Some, such as Italy and Peru, focused heavily on containing contagion, and protecting population health and health systems, quickly closing borders and adopting lockdowns; others, such as Brazil and Sweden, took more hands-off approaches whether in the name of "keeping economies open" or preserving individual choice (and responsibility). Both approaches exposed and exacerbated - the endemic plague of social inequality in many countries: lockdowns disproportionately hurt workers in informal economies, children who could not study on-line, and marginalised groups, including persons living with disabilities. Allowing COVID-19 to rage and deflecting state responsibility onto individuals also disproportionately affected diverse poor and marginalised people who often live in overcrowded conditions and have the least access to health systems. ${ }^{1}$ As Amnesty International's report for 2020

\footnotetext{
* Alicia Ely Yamin is a Lecturer on Law and Senior Fellow at the Petrie-Flom Center for Health Law Policy, Biotechnology and Bioethics at Harvard Law School, and Adjunct Senior Lecturer at the Harvard TH Chan School of Public Health.

** Stefania Negri is Associate Professor of International Law at the School of Law of the University of Salerno, and Director of the 'Observatory on Human Rights: Bioethics, Health, Environment'.

*** Roojin Habibi is a Doctoral Student at Osgoode Hall Law School and Research Fellow at the Global Strategy Lab, York University.

$1 \quad$ See Joelle Grogan, 'States of Emergency. Analysing Global Use of Emergency Powers in Response to Covid-19' (2020) 22 European Journal of Law Reform, 338; Alicia Ely Yamin (ed), 'Global Responses to COVID-19: Rights, Democracy, and the Law', at <https://blog .petrieflom.law.harvard.edu/symposia/global-responses-covid19-rights-democracylaw/> last accessed (as any subsequent URL) on 8 June 2021.
} 
stated, the pandemic revealed, and sometimes aggravated, existing patterns of human rights abuses and inequalities.' ${ }^{2}$ Oxfam's 2021 report, 'The Inequality Virus', details the intersecting dimensions of the inequality unmasked by this virus, and notes economists predict the pandemic will only exacerbate gaping social divides, as while millions were thrown into extreme poverty the world's richest ten people increased their wealth by a staggering USD $\$ 540$ billion in $2020^{3}$

Throughout history epidemics have laid bare government indifference to population suffering, extended state powers and challenged individual freedoms, exploited existing social inequalities, and raised questions about the fitness for purpose of governance institutions. However, the unprecedented magnitude and duration of the Covid-19 pandemic - called by the UN Secretary-General the 'biggest international crisis in generations' ${ }^{4}$ - has raised these questions to the level of global concerns. Further, CoviD-19 struck a world in which decades of deepening neoliberal legality and governance, in areas from financial deregulation to intellectual property to taxation, had increased private capital and undermined both public resources and capacities, including with respect to health systems. ${ }^{5}$

In this context, few States proved up to the challenge of responding to a little-understood and fast-spreading virus in a manner consistent with intersecting obligations stemming from the International Health Regulations (IHR) and widely ratified international human rights treaties. ${ }^{6}$ Relevant human rights standards had been set in treaties and case law from supra-national courts together with interpretive guidance issued by human rights treatymonitoring bodies (TM Bs), in general comments and recommendations, and in some cases were further clarified by international organisations and UN TM Bs and the Human Rights Council in the context of the Covid-19 pandemic. ${ }^{7}$

2 Amnesty International, 'Amnesty International Report 2020/21: The State of the World's Human Rights' (2021) at <https://www.amnesty.org/en/documents/polıo/3202/2021/en/>.

3 Oxfam, 'The Inequality Virus' (2021) at <https://www.oxfamamerica.org/explore/research -publications/inequality-virus/>.

4 António Guterres, 'The World Faces a Pandemic of Human Rights Abuses in the Wake of Covid-19', The Guardian (London, 22 February 2021).

5 See Alicia Ely Yamin, When Misfortune Becomes Injustice: Evolving Human Rights Struggles for Health and Social Equality (Stanford University Press 2020); Jedediah Britton-Purdy et al., 'Building a Law-and-Political-Economy Framework: Beyond the Twentieth-Century Synthesis' (2020) 129 The Yale Law Journal, 1784.

6 See Grogan (n 2); Yamin (n 2).

7 oHChr, Compilation of Statements by Human Rights Treaty Bodies in the Context of COVID-19 (Geneva 2020) at <https://www.ohchr.org/Documents/HRBodies/TB/Covidig/ External_TB_statements_Covidig.pdf>; HR Council, Resolution 46/4, Human rights, democracy and the rule of law (23 March 2021). 
Nonetheless, the IHR were quickly sidelined in pandemic responses as States raced to close borders, and there has been a notable gap between international normative commitments related to human rights and national legal responses.

The UN Secretary-General António Guterres denounced the 'pandemic of human rights abuses in the wake of CoviD-19', while openly deploring the fact that States used the outbreak 'as a pretext in many countries to crush dissent, criminalise freedoms and silence reporting.' ${ }^{8}$ At the same time, while countries that did follow procedural requirements regarding notification of derogations under the international and regional human rights treaties violated key provisions regarding fundamental rights, others that effectively circumscribed the use of emergency powers, and have been lauded for their management of the pandemic, often did not do so. ${ }^{9}$ Some failure to procedurally notify derogations can be attributed to tremendous empirical uncertainty associated with this new coronavirus, which also caused States to invoke the precautionary principle to justify additional measures adopted under international health law. However, the dismally widespread institutional failures regarding the protections of economic and social rights (ESR), as well as infringements of civil and political rights, suggest more structural problems in the architecture of international human rights law.

In assessing why the normative scaffoldings in international law that had been built up over decades often seemed to crumble like sandcastles when the first wave of CoviD-19 struck, the way in which plural democracies should manage both scientific uncertainty and competing normative values warrants further exploration. In this article we seek to contribute to ongoing discussions about the appropriate normative responses, and in particular to illuminate the need for further theorisation of relevant guiding principles as well as the imperative of democratically-legitimate decision making in health emergencies. The article proceeds as follows. In Part 2, we set out standards related to public health emergencies under the IHR surfacing the widespread reliance on the precautionary principle in state practice during CoviD-19. In Part 3, we turn to international human rights law, and explain requirements regarding derogation and limitations as they relate to emergencies such as Covid-19. We note the need for further consideration of ways to afford enhanced accountability through notifications of derogations to international bodies as they are amended over time, as well as the need for understanding the justification

8 See Guterres (n 4$)$.

9 Joelle Grogan and Alicia Ely Yamin, 'A Functionalist Approach to Analyzing Legal Responses to Covid-19 Across Countries: Comparative Insights from Two Global Symposia' in I. Glenn Cohen et al. (eds), Covid-19 and the Law: Disruption, Impact and Legacy (cup 2022). 
for de facto restrictions of health and other economic and social rights. Few restrictions have complied with requirements regarding limitations of rights under international law and many have directly undermined core obligations, including of the right to health. We conclude that the inflection point caused by the pandemic calls for broader reflections on these gaps in international law, as well as the need to focus more attention on the infrastructures for fair and solidaristic provision of social and economic rights, including health.

\section{2 \\ The International Health Regulations: Context, Concepts and Challenges Exposed by covid-19}

As of this writing, there are ongoing discussions regarding a proposal for a pandemic treaty, or reform of the IHR, which was last revised in 2005. ${ }^{10}$ Work on the current IHR began in 1995, just as the World Trade Organization (WTO) and a stable normative regime that fostered liberalisation of international trade, which was perceived as essential to neoliberal globalisation, were established. The HIV/AIDS pandemic, among other things, had elevated concerns over the global transmission of infectious diseases. ${ }^{11}$ By the time the current IHR were adopted by the World Health Assembly in $2005,{ }^{12}$ the world did not just have evidence of coordination and cooperation failures during SARS pandemic. Emerging threats of bioterrorism (e.g., anthrax in the aftermath of $9 / 11$ ) and intensified concerns regarding climate change, and conflict-driven displacement all fostered additional concerns regarding the links between

10 See Haik Nikogosian and Ilona Kickbusch, 'The Case for an International Pandemic Treaty' (2021) BMJ 372 (25 February 2021); Jorge Viñuales, Suerie Moon, Ginevra Le Moli, Gian-Luca Burci, 'A Global Pandemic Treaty Should Aim for Deep Prevention' (2021) The Lancet (28 April 2021); Sakiko Fukuda-Parr, Paulo Buss, Alicia Ely Yamin, 'Pandemic Treaty Needs to Start with Rethinking the Paradigm of Global Health Security' (2021) BMJ Global Health 6:eoo6392 (4 June 2021); Gian Luca Burci and Stefania Negri, 'Governing the Global Fight against Pandemics: The wHo, the International Health Regulation, and the Fragmentation of International Law' (2021) 53 New York University Journal of International Law \& Politics, 501.

11 See Gro Harlem Brundtland, 'Global Health and International Security' (2003) 9 Global Governance: A Review of Multilateralism and International Organizations 417; Catherine Lo Yuk-ping and Nicholas Thomas, 'How Is Health a Security Issue? Politics, Responses and Issues' (2010) 25 Health Policy and Planning, 447.

12 World Health Assembly Res WHA58.3, Revision of the International Health Regulations, Annex (23 May 2005). The IHR are in force as of 15 June 2007 and bind all wHO Member States plus the Vatican City and Liechtenstein. 
public health and national security. ${ }^{13}$ The UN Security Council invoked this relationship in 2000 when it first recognised that the HIV epidemic posed 'a potential risk to stability and security.'. ${ }^{4}$

Against this backdrop of ever expanding networks of exchange in the financialized global economy, coupled with a perception of threats posed to national security by the spread of disease, the purpose and scope of the revised IH R 2005 were to 'prevent, protect against, control and provide a public health response to the international spread of disease in ways that are commensurate with and restricted to public health risks, and which avoid unnecessary interference with international traffic and trade. ${ }^{15}$ In providing a binding legal framework to govern 'public health emergencies of international concern' (PHEICs), ${ }^{16}$ the IHR set up a challenging interplay between public health goals and other collective interests including freedom of trade, environmental safety and national security. ${ }^{17}$ One important innovation characterising the revised IHR 2005 was the inclusion of certain rights-related protections in the management of and response to cross-border health risks.

The IHR set out respect for the dignity, human rights and fundamental freedoms of persons and travellers as a 'guiding principle' in their implementation in article 3, paragraph 1, and include a number of additional, specific provisions regulating the treatment of international travellers and natural persons

13 See, for further study, Andrew T. Price-Smith, The Health of Nations: Infectious Disease, Environmental Change, and Their Effects on National Security and Development (MIT Press 2001).

14 UNSC Res 1308 (17 July 2000) UN Doc S/RES/1308, para. 1. The Security Council has invoked the relationship subsequently in 2014 and 2018 , when it declared a 'threat to international peace and security' from the Ebola outbreak in West Africa and the Democratic Republic of Congo, respectively; and in 2020, where it noted that 'the unprecedented extent of the CoviD-19 pandemic is likely to endanger the maintenance of international peace and security'. See UNSC Res 2177 (18 September 2014) UN Doc S/RES/2177; UNSC Res 2439 (3o October 2018) UN Doc S/RES/2439, paras. 2, 4, 7; UNSC Res 2532 (1 July 2020) UN Doc S/RES/2532; UNSC Res 2565 (26 February 2021) UN Doc S/RES/2565. For further discussion on the health-security paradigm, see Stefania Negri, 'Communicable Disease Control' in Gian Luca Burci and Brigit Toebes (eds), Research Handbook on Global Health Law (Edward Elgar Publishing 2018) 265, 291-297; Id., 'Introductory Note to United Nations Security Council Resolution 2532 (July 1, 2020)' (2021) 6o International Legal Materials, 24.

$15 \quad$ IHR (n 12) art. 2.

16 Ibid., art. 12. Pursuant to art. 1 IHR, "public health emergency of international concern" means an extraordinary event which is determined, as provided in these Regulations: (i) to constitute a public health risk to other States through the international spread of disease and (ii) to potentially require a coordinated international response'.

17 See David P. Fidler, 'From International Sanitary Conventions to Global Health Security: The New International Health Regulations' (2005) 4 Chinese Journal of International Law, $325,326$. 
at points of entry and the health measures applicable to them. ${ }^{18}$ Further, measures adopted by States must be consistent with the object and purpose of $\mathrm{IHR}$, as well as other relevant obligations under international law, which implies such measures should meet the relevant requirements imposed under international human rights law, as discussed below. Just as freedom of information is necessary for markets to function, so too is freedom of movement and protections for travellers necessary for cross-border traffic and trade that sustain the global economy. Further, governments have an interest in reciprocal protections for their citizens, just as in other international agreements regarding prisoner transfers, migrant workers and the treatment of prisoners of war. In line with this understanding of the IHR, together with scientific principles and evidence, certain internationally agreed human rights standards should inform assessments of the legality of public health responses to cross-border disease outbreaks. ${ }^{19}$

Given that the IHR are principally concerned with imposing rationality on public health responses which also may have inadvertent consequences on traffic and trade, article 43 of the $\mathrm{IHR}^{20}$ imposes substantive and procedural requirements on States that seek to adopt public health measures in addition to or different from those issued by the WHO as temporary recommendations under article $15 .{ }^{21}$ In terms of substance, such measures should be based on 'necessity, proportionality' and 'scientific risk assessment'. Any such measures should not be 'more restrictive of international traffic and not more invasive or intrusive to persons than reasonably available alternatives that would achieve the appropriate level of health protection. ${ }^{22}$ As a matter of procedure, national 'additional health measures' significantly interfering with international traffic (e.g., travel bans, refusal of entry or departure of international travellers, baggage and goods, or their delay for more than 24 hours) must be reported

18 See IHR (n 12), arts. 23 (prior informed consent), 32 (respectful treatment of travellers), 42 (non-discrimination) and 45 (confidentiality of health information).

19 Ibid., arts. 12,17 and 43.

20 See Roojin Habibi et al., 'The Stellenbosch Consensus on Legal National Responses to Public Health Risks: Clarifying Article 43 of the International Health Regulations' (2020) International Organizations Law Review (Advance Articles) <https://brill.com/view/ journals/iolr/aop/article-10.1163-15723747-2020023/article-10.1163-15723747-2020023.xml>. Pursuant to art. 1 IHR, "'temporary recommendation" means non-binding advice issued by wHO pursuant to Article 15 for application on a time-limited, risk-specific basis, in response to a public health emergency of international concern, so as to prevent or reduce the international spread of disease and minimize interference with international traffic'. 
to the wHO together with their public health rationale and relevant scientific information, within 48 hours from their implementation. ${ }^{23}$

It is 'scientific risk assessment' - which is based on scientific principles, available scientific evidence or any available specific guidance or advice from WHO - that forms the basis for justifications of proportionality and necessity. The IH R vaguely outlines the sources and standard of evidence that States should consider when deciding to implement additional health measures, noting that 'scientific principles' are 'the accepted fundamental laws and facts of nature known through the methods of science,' and 'scientific evidence' comprises 'information furnishing a level of proof based on the established and accepted methods of science.' ${ }^{4}$ The provision offers no further guidance on the threshold level of evidence and/or proof that might constitute "sufficient" scientific evidence. In essence, the requirement of scientific risk assessment should be read in light of the IHR's overall aim of reducing irrational or arbitrary reactions that have the potential to be both ineffective and discriminatory.

However, COVID-19 laid bare the limitations of tying the legitimacy of government responses to assessments of the 'probability that a harmful event will occur, and the severity of its effects'. ${ }^{25}$ Mathematical models for mortality, produced by the Institute for Health Metrics and Evaluation and others were incorrect as often or more so than they were correct. ${ }^{26}$ The science behind the effectiveness of various packages of public health measures also evolved constantly over the past year. Scientific uncertainty has tinged our understanding of and response to - among other things - SARs-CoV-2's mode of transmission (e.g., aerosol versus droplet transmission), incubation period, fatality rate, and the effectiveness of various non-pharmaceutical interventions (e.g., such as lockdowns, school closures, travel restrictions and masks) in curtailing viral transmission. ${ }^{27}$

Thus, it is unsurprising that during the first months of 2020, when very little was known about the SARs-CoV-2 virus, the vast majority of States

23 Ibid., art. 43(5).

24 Ibid., arts. 1, 43(2), emphasis added.

25 Lawrence O. Gostin and Lindsay F. Wiley, Public Health Law: Power, Duty, Restraint (University of California Press 2016) 56 .

26 Lyndon P. James et al., 'The Use and Misuse of Mathematical Modeling for Infectious Disease Policymaking: Lessons for the Covid 19 Pandemic' (2021) 41 Medical Decision Making, 379. See at <https://covidig.healthdata.org/global?view=cumulative-deaths\& tab $=$ trend $>$.

27 Julian W. Tang, 'COVID-19: Interpreting Scientific Evidence - Uncertainty, Confusion and Delays' (2020) 20:653 BMC Infectious Diseases, 2. 
that notified the wHO of the adoption of additional measures under article 43 of IHR - mainly concerning travel bans and restrictions of cross-national movement - had to justify their actions on the basis of "precaution" rather than scientific evidence. The wно Director-General reported that, as of 28 March 2020 - eight weeks after a PHEIC was declared - 136 States Parties had notified to wHo the implementation of additional health measures classified as significantly interfering with international traffic and provided their public health rationale. By 4 February 2021, 194 out of the 196 States Parties to the IHR had issued notifications of additional health measures. The rationale provided by these States was invariably related to uncertainties about the new virus and its animal origins; insufficient knowledge about the epidemiology of the disease and its full clinical spectrum; the absence of a specific treatment or vaccine; and the vulnerabilities of public health response systems in case of importation of the disease, in particular in the small island developing States. ${ }^{28}$

The wHo Director-General conceded that the resort to precautionary measures aimed at minimising the spread of the virus was understandable in the first phase of the pandemic. Nevertheless, he stressed that while the evidence showed that restriction of movements during the early containment phase of an outbreak might allow affected countries to implement sustained response measures and non-affected countries to gain time to initiate and implement effective preparedness measures, such restrictions should be short in duration, proportional to the public health risks and reconsidered regularly as the situation evolves. ${ }^{29}$ However, the idea that precaution was only warranted by a need for containment in "early containment phases" calls for interrogation as the various waves of COVID-19 have affected different regions in uneven ways, interacting with cumulative devastation in already precarious and underfunded health systems with variable capacities to obtain such basic equipment as oxygen concentrators. Likewise, while export restrictions generally pose significant obstacles to transnational response, they may be necessary for lower-income countries to maintain a domestic supply of basic materials to produce glass vials or personal protective equipment, in the face of unfettered bidding by wealthier countries and non-State actors in international markets. Moreover, in COVID-19, the spread of mutations amid a global vaccine

28 wHo, Annual Report on the Implementation of the International Health Regulations (2005). Report by the Director-General (12 May 2020) A73/14, paras. 15-16; wHO, Implementation of the International Health Regulations (2005). Report by the Director-General (12 May 2021) A74/17, paras. 21-23.

Ibid., para. 23 . 
apartheid has left many countries without a critical tool to prevent death and severe disease. Thus, formally treating all countries equally despite their unequal situations perpetuates the rigidly colonialist architecture of global health; COVID-19 has revealed the need for a more nuanced and contextualised approach to assessing precaution and proportionality, and their relation to other legal regimes underpinning global governance for health, including but not limited to the TRIPS agreement. ${ }^{30}$

Two high-profile reviews of the pandemic response led by groups of independent experts were considerably more forceful in denouncing the IHR's lack of provision for the urgency of pandemic response, including precautionary measures. The Independent Panel for Pandemic Preparedness, for instance, deplored the fact that the 'the legally binding IHR (2005) are a conservative instrument as currently constructed and serve to constrain rather than facilitate rapid action' 31 and the Review Committee on the Functioning of the International Health Regulations during the COVID-19 Response (IH R Review Committee on COVID-19) similarly characterised the concept as a "no regrets" principle when dealing with a new pathogen, and explicitly called for a more assertive use of the precautionary principle in the face of new pathogens. ${ }^{32}$

Crudely entrenching the precautionary principle in international and transboundary responses to public health crises carries the risk of conferring excessive deference to States prone to abusing emergency powers and to authoritarian drifts, which includes many. Further, it could undermine incentives for States to strike fair balances between competing interests in rational, evidence-based and democratic ways, and in turn exacerbate ongoing national and global socio-economic situations. In this regard, the IHR Review Committee on COVID-19 noted that precautionary measures should 'still be proportional to the perceived threat, non-discriminatory, continuously reviewed in light of new knowledge and applied in accordance with the IHR.'33 At the international level, ensuring compliance of evolving public health measures with proportionality and necessity requirements set out in the IHR as well as

30 Agreement on Trade-Related Aspects of Intellectual Property Rights, Annex C to the Marrakesh Agreement Establishing the World Trade Organization, 15 April 1994.

31 Independent Panel for Pandemic Preparedness, covid-19: Make It the Last Pandemic (2021) $26<$ https://theindependentpanel.org/mainreport/>.

32 Review Committee on the Functioning of the International Health Regulations (2005) during the Covid-19 response the, Report of the Review Committee on the Functioning of the International Health Regulations (2005) during the Covid-19 response (30 April 2021), para. 96 <https://www.who.int/publications/m/item/a74-9-who-s-work -in-health-emergencies $>$.

Ibid., para. 96. 
international human rights law remains at the core of promoting effective as well as just responses in global health emergencies. ${ }^{34}$ Yet the covid-19 pandemic has exposed significant lacunae in the legal framework of pandemic response.

In sum, the IHR enshrine a global health security regime, which is intended to ensure evidence-based public health measures are adopted at the national level, with the aim of minimising disruptions to international traffic and trade, including curbing some human rights abuses of travellers and other persons. However, the COVID-19 pandemic has revealed a substantial need for further theorisation in relation to the profound scientific uncertainty that will likely characterise future pandemics as well as climate change-driven health crises. In turn, there is an imperative both for developing substantive guidelines to inform a reasoned approach to precaution and proportionality, which take account of the relation between pandemic response and other international legal regimes that entrench structural inequalities, as well as strengthening democratically legitimate processes for striking an appropriate balance between precaution and proportionality in plural societies. Ultimately, in situations of radical uncertainty, where reasonable people can disagree about the effectiveness and distributional impacts of measures in a specific context, the legitimacy of State decisions hinges on the democratic legitimacy of the process for making such decisions.

International Human Rights Law: Emergencies, Derogations and Limitations for Public Health Reasons

If protections for travellers and other persons who find themselves within a State's territory are instrumental to maintaining a robust international regime of global exchange, public health emergencies and concerns are among exceptional circumstances that allow States to limit or suspend obligations under both international human rights law and international trade regimes. Further, any suspension of obligations under international legal regimes should be interpreted in light of the purposes it serves and the distributional consequences it produces on the effective enjoyment of human rights in practice.

For example, previous experience with HIV/AIDS illustrated that it is absolutely essential for national governments to be able to determine that situations constitute emergencies under the Doha Declaration on the TRIPS

34 See in general Sarah Joseph, 'International Human Rights Law and the Response to the Covid-19 Pandemic' (2020) 11 Journal of International Humanitarian Legal Studies, 249. 
Agreement and Public Health, in order to circumvent some of the barriers of intellectual property restrictions on access to medicines. Paragraph 5 (c) of the Doha Declaration states: 'Each member has the right to determine what constitutes a national emergency or other circumstances of extreme urgency, it being understood that public health crises, including those relating to HIV/ AIDS, tuberculosis, malaria and other epidemics, can represent a national emergency or other circumstances of extreme urgency'.35 The sweeping COVID-19 pandemic has revealed that the reporting and justification conditions attached to using TRIPs flexibilities to issue compulsory licenses (i.e., on a product-by-product basis pursuant to paragraph 31(b)) are far too onerous to be consistent with international human rights law protections for rights to health and life. ${ }^{36}$

With respect to human rights treaties, as has been pointed out by Gerald Neuman and other leading scholars, derogation and limitation clauses in and of themselves should not be construed as weakening international law, but rather enabling the necessary escape valves to address national emergencies through a variety of tools. ${ }^{37}$ Gross and Ní Aoláin refer to "models of accommodation" to describe a broad range and form of domestic design of both states of emergency regimes and constitutional and legal safeguards on their use. ${ }^{38}$ Nonetheless, there is broad consensus in international law that the use of emergency powers to suspend guarantees, which have historically been invoked in relation to conflict and national security concerns, opens the possibility of excessive restrictions on civil and political rights, discrimination against minorities, and the failure to re-establish normal institutional checks and balances following a time-limited emergency. ${ }^{39}$

35 Wто, The Doha Declaration on the trips Agreement and Public Health, wT/Min(o1)/ DEC/W/2, 14 November 2001, para. 5 (c).

36 CESCR, 'General Comment no. 25 (2020) on Science and Economic, Social and Cultural Rights (article 15 (1) (b), (2), (3) and (4) of the International Covenant on Economic, Social and Cultural Rights)' (30 April 2020) E/C.12/GC/25, para. 69 .

37 Gerald L. Neuman, 'Constrained Derogation in Positive Human Rights Regimes', in Evan J. Criddle (ed), Human Rights in Emergencies (CUP 2016) 15. See also Jaime Oraa, Human Rights in States of Emergency in International Law (Clarendon Press 1992); Anna-Lena Svensson-McCarthy, The International Law of Human Rights and States of Exception (Martinus Nijhoff 1998); Emanuele Sommario, 'Limitation and Derogation Provisions in International Human Rights Treaties and Their Use in Disaster Settings', in Flavia Zorzi Giustiniani, Emanuele Sommario, Federico Casolari and Giulio Bartolini (eds), Routledge Handbook of Human Rights and Disasters (Routledge 2018) 98.

38 Oren Gross and Fionnuala Ní Aoláin, Law in Times of Crisis: Emergency Powers in Theory and Practice (CUP 2006).

39 Eric A. Posner and Adrian Vermeule, Terror in Balance: Security, Liberty, and the Courts (OUP 2007). 
Therefore international human rights treaties, including the International Covenant on Civil and Political Rights (ICCPR), ${ }^{40}$ the American Convention on Human Rights (ACHR), ${ }^{41}$ and the European Convention on Human Rights $(\mathrm{ECHR})^{42}$ together with institutions that interpret them, provide guidelines for the design of safeguards on the use of exceptional power that requires derogating from international obligations, which are premised on: (i) identifying certain non-derogable rights; and (ii) requiring the use of emergency powers to be proportionate, necessary, non-discriminatory and temporary in nature. ${ }^{43}$

By contrast, limitation clauses, which are equally relevant to public health emergencies as discussed further below, generally do not require a state of exception, and are not necessarily subject to temporal limitations. Some scholars and practitioners, such as Mexican Supreme Court Justice Alfredo Gutiérrez Ortiz Mena, argue that abuses are equally likely where formally declared exceptions have not been declared, and that courts should therefore exercise heightened review ("strict scrutiny") of the arrogation of ordinary powers through limitation of rights by the executive even in times of crisis. ${ }^{44}$ But perhaps what CoviD-19 has most sharply illuminated is the need to address de facto restrictions on ESR, including health-related rights, in health emergencies that stem from resource allocation decisions which would ordinarily be contemplated under article 2(1) of the ICESCR.

\subsection{Derogations}

Major human rights conventions include clauses that permit States Parties to suspend or derogate from certain protective obligations when exceptional circumstances and emergency situations arise that threaten the life of the nation or which amount to an armed conflict. For example, article 4(1), of the ICCPR reads

In time of public emergency which threatens the life of the nation and the existence of which is officially proclaimed, the States Parties to the

$40 \quad$ International Covenant on Civil and Political Rights, 16 December 1966.

41 Convention for the Protection of Human Rights and Fundamental Freedoms, better known as the European Convention on Human Rights, 4 November 1950.

42 American Convention on Human Rights, 22 November 1969.

43 For analysis in the context of the pandemic, see Cassandra Emmons, 'International Human Rights Law and COVID-19 States of Emergency' (Verfassungsblog, 25 April 2020) <https:// verfassungsblog.de/international-human-rights-law-and-covid-19-states-of-emergency/>. Comments of Alfredo Gutiérrez Ortiz Mena, 'Constitutional Democracy and the Role of High Courts in Times of Crisis: The Case of Mexico' (23 October 2020) <https:// petrieflom.law.harvard.edu/events/details/constitutional-democracy-and-the-role-of -high-courts-in-times-of-crisis>. 
present Covenant may take measures derogating from their obligations under the present Covenant to the extent strictly required by the exigencies of the situation, provided that such measures are not inconsistent with their other obligations under international law and do not involve discrimination solely on the ground of race, colour, sex, language, religion or social origin.

Likewise, article 15(1) of the ECHR reads

In time of war or other public emergency threatening the life of the nation any High Contracting Party may take measures derogating from its obligations under this Convention to the extent strictly required by the exigencies of the situation, provided that such measures are not inconsistent with its other obligations under international law.

Article 27(1) of the ACHR, drafted largely during the 1960s, was shaped both by the UN and European systems and experiences with state practice in the region

In time of war, public danger, or other emergency that threatens the independence or security of a State Party, it may take measures derogating from its obligations under the present Convention to the extent and for the period of time strictly required by the exigencies of the situation, provided that such measures are not inconsistent with its other obligations under international law and do not involve discrimination on the ground of race, color, sex, language, religion, or social origin.

The contrast between the ACHR's broader language and the ICCPR's use of 'discrimination solely on' prohibited grounds, which limits the proscription on discrimination to a narrow slice of arbitrary discrimination exemplifies the reflections on authoritarian state practice in Latin America.

Other regional differences are of note as well. For example, the European Social Charter echoes the ECHR, allowing for derogations in times of war and other public emergency threatening the life of the nation to the extent strictly required by the exigencies of the situation, provided that such measures are not inconsistent with its other obligations under international law'45 By contrast, the African Charter on Human and People's Rights (African Charter) 
contains no provision for derogation even for civil and political rights that is equivalent to these other treaties. ${ }^{46}$

Under international law, some rights are not subject to derogation. Some such rights, as well as the obligations stemming therefrom, have achieved the status of jus cogens or peremptory norms: the right to life, freedom from torture and cruel, inhuman and degrading treatment, freedom from slavery, slave-trade and servitude, and freedom from ex post facto laws, which are enshrined in the ICCPR, the ECHR, the ACHR, among others. ${ }^{47}$ Additional rights, that do not have the same status, are specifically identified in individual human rights conventions. Common to the ICCPR and the ACHR are recognition as a person before the law, and the right to freedom of thought, conscience and religion. The ICCPR alone declares non-derogable the right to be free from imprisonment for failure to perform a contractual obligation, while the ECHR, with Protocols, considers the freedom from double jeopardy and abolition of the death penalty non-derogable. The ACHR uniquely adds protection of the family, rights of the child, the right to a nationality, the right to participate in government, and fundamental judicial guarantees to the list of non-derogable rights.

Further, derogations must meet requirements of necessity, proportionality, non-discrimination, ${ }^{48}$ limitations on scope and duration, and be consistent with the State's other obligations under international law. Strict necessity has been interpreted to mean that there be an actual threat to the life of the nation which calls for suspension of rights above and beyond the possibility of simply imposing restrictions under relevant limitation clauses. ${ }^{49}$ The Siracusa Principles on the Limitation and Derogation Provisions in the International Covenant on Civil and Political Rights (Siracusa Principles), ${ }^{50}$ as well as the Human Rights Committee's (HRC) General Comment No. 29 on Article 4 of the ICCPR, ${ }^{51}$ together with the case-law of the Inter-American and European Courts of Human Rights (ECtHR) ${ }^{52}$ collectively provide persuasive guidance in

46 African Charter on Human and People's Rights, 27 June 1981.

47 See art. 4(2) ICCPR; art. 15(2) ECHR; art. 27(2) ACHR.

48 See distinctions between ACHR and ICCPR discussed above.

49 See CHR, Siracusa Principles on the Limitation and Derogation Provisions in the International Covenant on Civil and Political Rights (hereinafter Siracusa Principles) (28 September 1984) E/CN.4/1985/4, Annex, para. 54; HRC, 'General Comment No. 29: States of Emergency (article 4)' (31 August 2001) CCPR/C/21/Rev.1/Add.11, para. 5.

50 Ibid.

$51 \quad$ Ibid.

$5^{2}$ See in general ECtHR, Guide on Article 15 of the European Convention on Human Rights. Derogation in times of emergency, updated on 31 August 2020. 
determining whether such a threat exists. For example, in addressing derogation under the ICCPR, the Siracusa Principles clarify that

A threat to the life of the nation is one that: (a) affects the whole of the population and either the whole or part of the territory of the state; and (b) threatens the physical integrity of the population, the political independence or the territorial integrity of the state or the existence or basic functioning of institutions indispensable to ensure and protect the rights recognized in the Covenant. ${ }^{53}$

General Comment No. 29 states that 'not every disturbance or catastrophe qualifies as a public emergency which threatens the life of the nation. ${ }^{54}$ Although such threats generally refer to traditional states of emergency, such as those deriving from an armed conflict, the HRC guidance suggests that States may invoke their right to derogate from the ICC PR in other contexts as well, such as in case of a natural catastrophe, mass demonstrations including instances of violence, or a major industrial accident, provided that they are 'able to justify not only that such a situation constitutes a threat to the life of the nation, but also that all their measures derogating from the Covenant are strictly required by the exigencies of the situation' 55

In the case of 'Lawless v. Ireland', the ECtHR stated that the natural and customary meaning of the words 'other public emergency threatening the life of the nation' under the ECHR is sufficiently clear and refers to 'an exceptional situation of crisis or emergency which affects the whole population and constitutes a threat to the organised life of the community of which the State is composed. ${ }^{56}$ The Court clarified that the threat to the life of the nation has to be 'actual' or 'imminent'. On multiple occasions the ECtHR has stressed that 'the existence of a public emergency must not serve as a pretext for limiting freedom of political debate, which is at the very core of the concept of a democratic

53 See Siracusa Principles (n 49) para. 39.

54 See General Comment No. 29 (n 49) para. 3.

55 Ibid., para. 5 .

$5^{6}$ ECtHR, 'Lawless v Ireland (No. 3)', Judgment (1 July 1961) para. 28. In this case, the applicant, suspected of being a member of the Irish Republican Army, alleged in particular that he had been held from July to December 1957 in a military detention camp in Ireland without being brought before a judge in the relevant period. In the circumstances of the case, the Court found that the Irish Government were justified in declaring that there was a public emergency threatening the life of the nation in Ireland and were thus entitled, applying the provisions of article 15(1) ECHR, to implement special detention powers and to take other measures derogating from their obligations under the Convention. 
society ${ }^{57}$ and that even in a state of emergency Member States 'must bear in mind that any measures taken should seek to protect the democratic order from the threats to it, and every effort must be made to safeguard the values of a democratic society, such as pluralism, tolerance and broadmindedness. 58

A fundamental safeguard of democratic commitments in international law is that states of emergency or exception be proclaimed by the competent national authorities in accordance with constitutional and statutory law; the imposition of measures that derogate from international obligations must be subject to judicial review; and notification of derogations be made to the relevant supra-national authority, together with justifications regarding the suspension and the temporal extent of the suspension. For example, article $27(3)$ of the ACHR reads

Any State Party availing itself of the right of suspension shall immediately inform the other States Parties, through the Secretary General of the Organization of American States, of the provisions the application of which it has suspended, the reasons that gave rise to the suspension, and the date set for the termination of such suspension.

According to the ECtHR's jurisprudence, the formal proclamation of the state of emergency ${ }^{59}$ and the official public notice of derogation ${ }^{60}$ are essential

57 See ECtHR, 'Mehmet Hasan Altan v Turkey', Judgment (20 March 2018) para. 210; 'Şahin Alpay v Turkey', Judgment (20 March 2018) para. 180. These cases concerned complaints by two journalists who had been arrested and detained following the attempted military coup of 15 July 2016. In both cases the Court observed that the Constitutional Court of Turkey, having examined from a constitutional perspective the facts leading to the declaration of a state of emergency, had concluded that the attempted military coup had posed a severe threat to the life and existence of the nation. In light of the Constitutional Court's findings and all other material available to it, the Court likewise considered that the attempted military coup had disclosed the existence of a "public emergency threatening the life of the nation" within the meaning of the Convention and thus justified the Turkish Government's derogations from the ECHR.

$58 \quad$ Ibid.

59 ECtHR, 'Brannigan and McBride v the United Kingdom', Judgment (26 May 1993), para. 68. The two applicants in this case, suspected members of the Irish Republican Army, complained about not having been brought promptly before a judge after their arrest. Referring to its judgment in 'Lawless (no. 3) v. Ireland', and making its own assessment in light of the evidence at its disposal as to the extent and effects of the terrorist violence in Northern Ireland and elsewhere in the United Kingdom, the Court found it not to be in doubt that there genuinely was a public emergency threatening the life of the nation in the circumstances.

6o European Commission of Human Rights, 'Cyprus v Turkey', Report of the Commission (4 October 1983), para. 67. This case concerned the situation existing in Northern Cyprus since the conducting of military operations in this region by Turkey in July and August 1974. 
elements to be taken into due consideration in scrutinising the legality and legitimacy of derogations. In this regard, it is worth underscoring that before the CoviD-19 pandemic began, whether and when a public health emergency could represent a 'public emergency which threatens the life of the nation' was an issue of debate and relevant practice was scant to non-existent. Indeed, with the only exception of Georgia's derogation to the ECHR in 2006, no practice was reported with regard to regional conventions, ${ }^{61}$ and only two cases were recorded in relation to derogations from the ICCPR. ${ }^{62}$ These cases occurred in 2006 and 2009 and concerned, respectively, the Georgian and Guatemalan notifications to the UN Secretary-General of a declaration of the state of emergency following the outbreaks of the H5N1 ("bird flu") and the A/ H1N1 ("swine flu") pandemics. In both cases, however, the emergency decrees adopted by these governments were almost immediately repealed or declared null and void by the competent national authorities. ${ }^{63}$ Later, notwithstanding the temporary recommendations issued by the IH R Emergency Committees on Ebola ${ }^{64}$ and poliovirus, ${ }^{65}$ stipulating that affected States should declare a national public health emergency, none of the countries concerned ever

The Cypriot Government had argued that Turkey continued to occupy $40 \%$ of the territory of the Republic of Cyprus and alleged violations by Turkey of certain Convention provisions. The Commission found that, in the absence of an official and public notice of derogation from Turkey, it could not apply article $15 \mathrm{ECHR}$ to the measures taken by Turkey in respect of persons or property in Northern Cyprus.

61 See ECtHR, Factsheet 'Derogation in time of emergency' (April 2021) <https://www.echr .coe.int/Documents/FS_Derogation_ENG.pdf>.

62 See Notifications under article 4(3) ICCPR, at $<$ https://treaties.un.org $>$.

63 For Georgia, see Presidential Decree No. 173 of 26 February 2006 on 'State of Emergency in the Khelvachauri district', approved by the Parliament of Georgia on 28 February 2006, and Presidential Decree No. 199 of 15 March 2006 on 'Abolishment of the State of Emergency in the Khelvachauri district', approved by the Parliament of Georgia on 16 March 2006. For Guatemala, see Government Decree No. 7-2009 of 6 May 2009, which was declared for a period of thirty days and limited the rights and freedoms contained in articles 12, 19 and 21 of the ICCPR. On 12 May 2009, by Government Decree No. 8-2009, the President of the Republic repealed Decree No. 7-20o9.

64 WHO Statement on the first meeting of the IHR Emergency Committee on the 2014 Ebola outbreak in West Africa, 8 August 2014.

65 wHо Statement on the meeting of the International Health Regulations Emergency Committee concerning the international spread of wild poliovirus, 5 May 2014. The Committee recommended that both infected and exporting States (Pakistan, Cameroon, and the Syrian Arab Republic) and infected but not-exporting States (Afghanistan, Equatorial Guinea, Ethiopia, Iraq, Israel, Somalia and particularly Nigeria) officially declare, at the level of head of State or government, that the interruption of poliovirus transmission was a national public health emergency. This recommendation was reiterated until the latest Statement of May 2017. 
issued any such declaration nor did they notify the UN Secretary-General of their intention to invoke article 4 of the ICCPR.

When COVID-19 broke out in 2020, twenty-three States notified declarations of states of emergency to the UN Secretary General under article 4(3) ICCPR. ${ }^{66}$ However, the vast majority of the 107 States that had in fact proclaimed a state of emergency ${ }^{67}$ did not notify the UN Secretary General, despite derogating from key treaty provisions. All States Parties to the ICCPR that invoked article 4 derogated from articles 12 (freedom of movement) and 21 (freedom of assembly); many of them (Dominican Republic, Ecuador, Estonia, Latvia, Paraguay, Peru, Romania) also added articles 17 (right to privacy) and 22 (freedom of association). A few States (Armenia, Colombia, Estonia, Georgia, Paraguay, Peru, Togo ${ }^{68}$ ) applied stricter regimes extending the derogation to articles 9 (right to liberty and security of the person), 13 (guarantees concerning the expulsion of foreigners), 14 (right to fair trial) and 19 (freedom of expression). Moreover, rather than setting out clear temporal limitations, in some cases derogation regimes remained in place from March 2020 to April or May 2021 (Ecuador, Latvia, Moldova, Dominican Republic and Peru).

Ten European States notified the Secretary General of the Council of Europe of their decision to apply article 15 ECHR. ${ }^{69}$ The other Contracting Parties to the ECHR chose a different path and did not activate article 15, implying their public health measures were only limitations on but not suspensions of rights. Virtually all States that invoked article 15 derogated from articles 8 (right to private life) and 11 (freedom of assembly and association) of the Convention, articles 1 (right to property) and 2 (right to education) of Protocol No. $1,{ }^{70}$ and article 2 (freedom of movement) of Protocol No. $4{ }^{71}$ Only Estonia and Georgia

66 Argentina, Armenia, Chile, Colombia, Dominican Republic, Ecuador, El Salvador, Estonia, Ethiopia, Georgia, Guatemala, Kyrgyzstan, Latvia, Namibia, Paraguay, Peru, Republic of Moldova, Romania, San Marino, Senegal, State of Palestine, Thailand, Togo.

67 The database 'COVID-19 Civic Freedom Tracker' reports that 107 States declared a state of emergency: see at $<$ https://www.icnl.org/CoviDigtracker/?location=\&issue=5\&date= \&type $=>$.

68 It is worth noting that Togo formally notified the UN Secretary-General under article 4(3) ICCPR only ex post facto, that is to say in May 2021 (<https://treaties.un.org/doc/ Publication/CN/2021/CN.151.2021-Eng.pdf $>$ ).

69 Albania, Armenia, Estonia, Georgia, Latvia, Moldova, North Macedonia, Romania, San Marino, Serbia. It is worth noting that not all European countries that derogated from the ECHR equally derogated from the ICCPR. Compare the list of States provided in (n 66) above.

70 Protocol to the Convention for the Protection of Human Rights and Fundamental Freedoms, 20 March 1952.

71 Protocol No. 4 to the Convention for the Protection of Human Rights and Fundamental Freedoms securing certain rights and freedoms other than those already included in the Convention and in the First Protocol thereto, 16 September 1963. 
took a more restrictive approach, suspending also articles 5 (right to liberty and security) and 6 (right to fair trial) of the Convention. Derogation regimes in Europe were mostly withdrawn between June and October 2020, with the exception of Latvia, Moldova and Georgia, that prolonged the emergency situation and extended the application of article 15 until February, April and July 2021, respectively.

Lacking significant case law from the ECtHR, ${ }^{72}$ the European Parliament provided a first-glance assessment of the proportionality of the most common public health measures adopted by European States, based on the previous jurisprudence of the Court. ${ }^{73}$ With regard to restrictions of liberty and freedom of movement, the European Parliament's report found that since the large majority of public health measures were limited in time, or subject to automatic sunset clauses, or included hardship clauses, they were likely to satisfy the standard of proportionality.' ${ }^{74}$ On other restrictions, the report concluded that they met the tests of legality and necessity, but it did not provide any assessment concerning proportionality. For example, it stated that confinement to one's home (except for shopping for essential items), though entailing a severe restriction of liberty, may amount to a deprivation of liberty only under certain conditions depending on several factors (such as surveillance by authorities, possibility to exercise outdoors, etc.). In contrast, it considered compulsory detention for quarantine purposes as a deprivation of liberty, in light of the fact that the ECtHR emphasised in 'Kuimov v. Russia' - the only case in which the application of a quarantine was considered - that this kind

$7^{2}$ As of June 2021, only a handful number of cases were submitted to the ECtHR alleging violations of fundamental rights due to anti-Covid measures. The only interesting case decided by the Court at the admissibility stage is 'Le Mailloux v France', where the applicant objected to the handling by the French State of the covid-19 emergency. The applicant complained of the failure by the State to fulfil its positive obligations to protect the lives and physical integrity of persons under its jurisdiction. The Court declared the application inadmissible, insofar as the applicant was complaining about the measures aimed to curb the propagation of the CoviD-19 virus among the whole population, but did not shown how he was personally affected. The Court reiterated that it did not recognise an actio popularis, meaning that applicants cannot complain about a provision of domestic law, a domestic practice or public acts simply because they appear to contravene the ECHR. See ECtHR, Factsheet COVID-19 health crisis, May 2021.

73 European Parliament Research Service, 'Upholding Human Rights in Europe during the Pandemic' (September 2020) <https://www.europarl.europa.eu/RegData/etudes/ BRIE/2020/652085/EPRS_BRI(2O20)652085_EN.pdf>.

74 Ibid., at 5. See also Jeremy McBride, 'Covid-19 and the European Convention on Human Rights' (ECHR Blog, 27 March 2020) <https://www.echrblog.com/2020/o3/an-analysis-of -covid-19-responses-and.html>. 
of restriction should be 'a temporary measure, to be discontinued as soon as circumstances permit' and that 'severe and lasting restrictions (...) are particularly likely to be disproportionate to the legitimate aims pursued. ${ }^{75}$ The report also recalled that the Court clarified that the detention of an infected person may only be used as a last resort in order to prevent the spreading of the disease' and only 'because less severe measures have been considered and found to be insufficient' to safeguard public health. ${ }^{76}$

Beyond the evident limitations of the overall descriptive approach taken by the European Parliament's report, it is clear that meaningful assessment of the proportionality and reasonableness of these measures remains in the purview of national courts and, upon exhaustion or demonstrated futility of domestic remedies, the ECtHR. Due to both institutional capacity as well as policies, the ECtHR cannot guarantee a timely review of derogation measures that would enable an adequate response to the suspension of guarantees: 'Under its current priority policy on examination of incoming cases, applications relating to derogatory measures do not appear as a separate category that enjoys priority'.77 In practice, in Europe as elsewhere, these safeguards depend upon the maintenance of democratic institutions including continual parliamentary scrutiny and timely independent judicial review.

In sum, the unpredictability and continually shifting nature of COVID-19 has surfaced challenges to the procedural requirements of defining temporal limitations on derogation, and effective oversight of proportionality as the pandemic conditions evolved through time. A central concern regarding states of exception is always that they do not result in permanent shifts of the

75 ECtHR, 'Kuimov v Russia', Judgment (8 January 2009) para. 96. This case concerned the applicant's complaint that he was denied access to his adoptive daughter, suffering from acute encephalomyelitis, following her placement by the authorities in intensive care and subsequently in foster care. The Court found a breach of the applicant's article 8 rights on account of the restrictions imposed by the authorities on his access to his daughter.

76 ECtHR, 'Enhorn v Sweden', Judgment (25 January 2005) para. 44. This case concerned the compulsory isolation of a homosexual for failure to comply with the measures prescribed by the county medical officer and aimed at preventing him from spreading the HIV infection. The Court found that the applicant's involuntary placement in a hospital for 18 months extending over a period of seven years amounted to a "deprivation of liberty" within the meaning of Article 5(1) of the Convention.

77 Kushtrim Istrefi, 'Supervision of Derogations in the Wake of COVID-19: A Litmus Test for the Secretary General of the Council of Europe' (EJIL:Talk!, 6 April 202O) <https:// www.ejiltalk.org/supervision-of-derogations-in-the-wake-of-covid-19-a-litmus-test -for-the-secretary-general-of-the-council-of-europe/>; see also Kanstantsin Dzehtsiarou, 'What Can the European Court of Human Rights Do in the Time of Crisis?' <https:// strasbourgobservers.com/2020/04/14/what-can-the-european-court-of-human-rights-do -in-the-time-of-crisis/>. 
balance of power towards the executive, undermining democratic states of law. In the context of the CoviD-19 pandemic, where drifts toward illiberalism, democratic decay ${ }^{78}$ and autocratisation were already evident before the pandemic, ${ }^{79}$ the threats relating to increasingly unaccountable executive dominance are particularly dramatic.

Against this backdrop, it is imperative to revisit notification procedures to facilitate ongoing amendments and dialogue to enhance external accountability, as empirical conditions evolve. In a democratic society, emergency decrees, even when initially justified, should quickly be replaced by legislation based on public debate, and be subject to independent scrutiny by the courts. Thus, any extensions of emergency decrees should be subject to additional notification, as well as to heightened justification requirements. Making the legitimacy of derogation conditional upon continually updated notifications and information regarding the institutional mechanisms for decision-making as well as individual rights reinforces that derogations are deviations from the extant legal order, and promotes principles of transparency and adherence to the rule of law. ${ }^{80}$

\subsection{Limitations}

In addition to derogation clauses, human rights treaties contain limitation clauses, which reflect the notion that rights are not absolute guarantees, and are subject to limits to meet States' interests in protecting public safety, order, health or morals, or national security. ${ }^{81}$ In some cases, such as the ICCPR, provisions for limitation on these grounds, including public health, attach to specific rights, such as freedoms of movement (article 12), expression (article 19), association (article 22), to manifest one's religion or beliefs (article 18), expulsion of foreign nationals (article 13), and public access to the criminal trials (article 14). Prohibitions on torture (article 7) and slavery (article 8) are not subject to limitations under the ICCPR. Likewise, the ACHR allows limitations on freedoms to manifest one's religion and beliefs (article 12), of

78 Tom Daly, 'Democratic Decay: Conceptualising an Emerging Research Field' (2019) 11 Hague Journal on the Rule of Law, 9 .

79 Kim Lane Scheppele, 'Autocratic Legalism' (2018) 85 University of Chicago Law Review, 545 .

8o See also Natasha Holcroft-Emmess, 'Derogating to Deal with covid 19: State Practice and Thoughts on the Need for Notification' (EJIL:Talk!, April 10, 2020) <https://www .ejiltalk.org/derogating-to-deal-with-covid-19-state-practice-and-thoughts-on-the-need -for-notification/>.

81 Arts. 12, 19, 21, 22 ICCPR; arts. 8-11 ECHR; art. 2 Additional Protocol No. 4 to ECHR; arts. 12, 13, 15, 16, 22 ACHR; arts. 5 and 8 Additional Protocol to ACHR; arts. 11-12 ACHPR. 
thought and expression (article 13), peaceful assembly (article 15), association (article 16), movement (article 22). Article 30 adds that such restrictions 'may not be applied except in accordance with laws enacted for reasons of general interest and in accordance with the purpose for which such restrictions have been established'.

Along the same lines, the ECHR allows similar interferences on the exercise of the right to private life (article 8), and on freedoms to manifest one's religion and beliefs (article 9), of expression (article 10), assembly and association (article 11), movement (article 2 of Protocol No. 4). In accordance with the ECHR and the jurisprudence of the ECtHR, restrictions are legitimate in so far as they comply with some fundamental substantive requirements, i.e. that they 'are prescribed by law and are necessary in a democratic society' and are proportionate to the legitimate aim pursued. The Court has clarified that "necessary" in this context does not have the flexibility of such expressions as "useful", "reasonable", or "desirable", but implies the existence of a "pressing social need" for the interference in question'. ${ }^{82}$ The Court also stated that a restriction on a Convention right cannot be regarded as "necessary in a democratic society" unless, amongst other things, it is proportionate to the legitimate aim pursued..$^{83}$

Most interestingly, the Court has stated that to determine the proportionality of a general measure it is necessary to assess the democratic process and circumstances underlying it. Such an assessment includes the quality of the relevant parliamentary and judicial review and the extent to which the government's decision-making process afforded due respect to the individual rights safeguarded by the Convention. ${ }^{84}$

While, as mentioned above, the African Charter does not contain any derogation clause, many provisions embed limitations that reflect the distinct recognition of correlative duties to rights and the emphasis placed upon

82 ECHR, 'Dudgeon v the United Kingdom', Judgment (22 October 1981) para. 51. In this case, the Court agreed with the Commission that Northern Ireland's criminalisation of homosexual acts between consenting adults was a violation of art. 8 ECHR.

83 Ibid., paras. 52-53. See also 'Z v Finland', Judgment (25 February 1997) para. 94. On this occasion the Court stated general principles concerning the importance of respecting confidentiality of health data; these considerations were especially valid as regards protection of confidentiality of information about a person's HIV infection, disclosure of which not compatible with art. 8 ECHR unless justified by an overriding requirement in the public interest.

84 ECtHR, 'A.-M.V. v Finland', Judgment (23 March 2017) paras. 82-84. The Court considered carefully but rejected a central tenet of the interpretation of Article 12 of the Convention of the Rights of Persons with Disabilities, namely that the will and preferences of an individual should always be determinative of any decision taken in their name. 
collective or people's rights. For example, article 6 of the Charter guarantees the right to liberty 'except for reasons and conditions previously laid down by law', article 8 ensures freedom of religion and conscience 'subject to law and order' and article 10 establishes the right to freedom of association 'provided that [the person] abides by the law'.

This provision-by-provision treatment in all of the aforementioned instruments contrasts with the broad application of limitations in article 29(2) of the Universal Declaration of Human Rights, ${ }^{85}$ as well as some other treaties. For example, in the International Covenant on Economic, Social and Cultural Rights (ICESCR), limitations also have general application across the Covenant but must be 'determined by law only in so far as this may be compatible with the nature of these rights and solely for the purpose of promoting the general welfare in a democratic society' ${ }^{\prime} 6$

Specific limitations clauses are not included in the ICESCR, with the exception of trade union rights. Article 5 contains a general saving clause that sets out that limitations may not be used to violate the rights in the ICESCR or otherwise under international law.

General Comments from the Committee on Economic Social and Cultural Rights (CESCR) have provided interpretive guidance as to the use of limitations in the context of specific rights, including the right to health and health-related rights. ${ }^{87}$ The European Social Charter similarly takes a blanket approach to limitations. ${ }^{88}$ While derogations are justified in times of armed

85 Universal Declaration of Human Rights, 10 December 1948. Art. 29(2) reads: 'In the exercise of his rights and freedoms, everyone shall be subject only to such limitations as are determined by law solely for the purpose of securing due recognition and respect for the rights and freedoms of others and of meeting the just requirements of morality, public order and the general welfare in a democratic society'.

86 Art. 4 ICESCR.

87 CESCR, 'General Comment No. 14 (2000) on the right to the highest attainable standard of health (article 12 of the international Covenant on Economic, Social and Cultural Rights)' (11 August 2000) E/C.12/2000/4, paras. 28-29; CESCR, 'General Comment No. 25 (2020) on science and economic, social and cultural rights (article 15 (1) (b), (2), (3) and (4) of the International Covenant on Economic, Social and Cultural Rights)' (3o April 2020) E/C.12/ GC/25, paras. 21-22.

88 ESC, 18 October 1961, art. 31(1) (Restrictions): "The rights and principles set forth in Part I when effectively realised, and their effective exercise as provided for in Part II, shall not be subject to any restrictions or limitations not specified in those parts, except such as are prescribed by law and are necessary in a democratic society for the protection of the rights and freedoms of others or for the protection of public interest, national security, public health, or morals'. 
conflict or of emergencies threatening the life of a nation, the application of limitation clauses is generally decided on a case-by-case basis.

Unlike derogations, limitations are widespread under international law, need not be formally notified and are not necessarily strictly limited in duration. However, limitations must be in accordance with the law, compatible with the nature of the rights protected by the Covenant, in the interest of legitimate aims pursued, and strictly necessary for the promotion of the general welfare in a democratic society. Further, under the ICESCR limitations must be proportional, which means that 'the least restrictive alternative must be adopted where several types of limitations are available. The CESCR has noted specifically that ' $[\mathrm{e}]$ ven where such limitations on grounds of protecting public health are basically permitted, they should be of limited duration and subject to review' 89

Fundamentally, limitations under article 4 of the ICESCR relate to situations where the exigencies of a situation call for flexibilities for States to make the necessary trade-offs to protect other rights; they are not meant to apply to restrictions on rights due to lack of available resources under article 2(1). ${ }^{90}$ However, as discussed below, COVID-19 has blurred these distinctions.

The Siracusa Principles, interpreted through treaty-monitoring bodies and supra-national courts over the last four decades, provide what has come to be authoritative guidance regarding what 'prescribed by law' means and the conditions for limitations on civil and political rights to be legitimately applied. Those Principles clarify that

Public health may be invoked as a ground for limiting certain rights in order to allow a State to take measures dealing with a serious threat to the health of the population or individual members of the population. These measures must be specifically aimed at preventing disease or injury, or providing care for the sick and injured. ${ }^{91}$

At the time the Siracusa Principles were adopted in the 1980s, widespread discriminations against persons living with HIV were in effect, which had no

89 CESCR, 'General Comment No. 14 (2000) on the right to the highest attainable standard of health (article 12 of the international Covenant on Economic, Social and Cultural Rights)' (11 August 2000) E/C.12/200o/4, paras. 28-29.

9o Philip Alston and Gerard Quinn, 'The Nature and Scope of States Parties' Obligations under the International Covenant on Economic, Social and Cultural Rights' (1987) 9 Human Rights Quarterly, 156, 193-97.

Siracusa Principles (n 49), para. 25 . 
basis in scientific evidence. Thus, interestingly, the Principles further suggest that in adopting restrictive measures in response to any national public health crisis, due regard should be paid the IHR that were then in effect, implying that national authorities have an obligation to abide by evidence-based measures in public health as a deterrent to potential discrimination and abuse. ${ }^{92}$ Despite scientific uncertainty regarding some aspects of COVID-19, requirements to provide a clear definition of the legitimate aim or reasons justifying the restrictions, be duly established pursuant to law, meet the necessity and proportionality tests, fulfil non-discrimination requirements, and establish an effective remedy in the event of violations are more relevant than ever.

In the context of CoviD-19, severe limitations were imposed in practice across a wide spectrum of human rights, but of particular note may be the tsunami of restrictions imposed on ESR, including but not limited to the right to health. Lockdowns affected rights from livelihoods to education. ${ }^{93}$ Many of these restrictions cannot be said to be "prescribed by law" as that phrase has been interpreted through the Siracusa Principles and the jurisprudence of regional courts. Restrictions on rights were often not subjected to debate, were not clear and accessible to everyone, and had arbitrary and unreasonable impacts on certain populations without adequate safeguards or effective remedies. For example, obligatory confinement produced an epidemic of gender-based violence (and ensuing health effects), ${ }^{94}$ which the CEDAw Committee has determined amount to 'torture or cruel, inhumane or degrading treatment' and therefore implies that freedom from such violence is a 'peremptory norm' of international law. ${ }^{95}$ Likewise, efforts to contain contagion

92 Art. 57(1) of the IHR provides that 'States Parties recognize that the IHR and other relevant international agreements should be interpreted so as to be compatible'. See Gian Luca Burci and Riikka Koskenmäki, 'Human Rights Implications of Governance Responses to Public Health Emergencies: The Case of Major Infectious Diseases Outbreaks' in Andrew Clapham and Mary Robinson (eds), Realizing the Right to Health (Ruffer \& Rub 2009) 346, at 352; Brigit Toebes, 'Human Rights and Public Health: Towards A Balanced Relationship' (2015) 19 The International Journal of Human Rights, 488, 496-501.

93 See in general CESCR, 'Statement on the coronavirus disease (COVID-19) pandemic and economic, social and cultural rights by the Committee on Economic, Social and Cultural Rights (6 April 2020) E/C.12/202O/1.

94 See in general Report of the Special Rapporteur on violence against women, its causes and consequences, Dubravka Šimonović, 'Intersection between the coronavirus disease (COVID-19) pandemic and the pandemic of gender-based violence against women, with a focus on domestic violence and the "peace in the home" initiative' (24 July 2020) UN Doc A/75/144.

95 CEDAW, 'General Recommendation No. 35 on Gender-Based Violence Against Women, Updating General Recommendation No. 19' (26 July 2017) CEDAW/C/GC/35, paras. 16, 25. 
fostered displacement of essential sexual and reproductive health services required only by persons who gestate, who are overwhelmingly women (e.g., abortion), and for whom access was already hampered pre-pandemic by 'medically unnecessary legal and policy barriers.' ${ }^{96}$ Further, the chaos unleashed by COVID-19 exacerbated inequities arising from variable decisions in federalist systems, where one province or state, or even municipality, might put in place restrictions that differed from a neighbouring geographic area, which is clearly in violation of the requirement that limitations on basic rights be effected pursuant to laws of national application. ${ }^{97}$ Although any deliberately retrogressive measures would be subject to necessity, proportionality and legality requirements as well as prohibitions on disproportionately affecting marginalised and vulnerable populations, the pandemic has exposed a significant normative gap in protecting ESR.

For example, restrictions widely affected access to 'core' obligations under a number of ESR including the right to health. In General Comment 3, 'The Nature of State Parties Obligations', the CESCR adopted the notion of an essential minimum level of ESR, including 'essential primary health care' arguing that such deprivation was prima facie evidence of failure to discharge obligations under the Covenant. ${ }^{98}$ The concept of a minimum threshold had been set out in the jurisprudence of the German constitutional court, and has subsequently been elaborated in the constitutional jurisprudence of a multitude of other countries, from Europe to Latin America, but its application to countries of varying resource levels and institutional capacities has been criticized as being either minimalistic or vague and unworkable. ${ }^{99}$

The illustrative enumeration in General Comment 3 was stark, but was never intended to be understood as invariant, or to be read in isolation from obligations relating to the progressive realisation of ESR under article 2(1). ${ }^{100}$ By the time it issued General Comment 14 in 200o, the CESCR had abandoned the

96 Šimonović (n 94) paras. $72-75$.

97 Nicole Huberfeld, Sarah H. Gordon \& David K. Jones, 'Federalism Complicates the Response to the Covid-19 Health and Economic Crisis: What Can Be Done?' (2020) 45 Journal of Health Politics, Policy and Law, 951.

98 CESCR, 'General Comment No. 14 (2000) on the right to the highest attainable standard of health (article 12 of the international Covenant on Economic, Social and Cultural Rights)' (11 August 2000) E/C.12/200o/4, para. 10.

99 See for example, Katherine Young, 'The Minimum Core of Economics and Social Rights: A Concept in Search of Content,' (2008) Yale Journal of International Law, 33.

100 CESCR, 'General Comment No. 3: The Nature of States Parties' Obligations (Art. 2, Para. 1, of the Covenant)' (14 December 1990) E/1991/23, para. 10. 
minimum threshold concept using a prima facie presumption to be rebutted by the State. Instead, the Committee set out an extensive list of 'basic' obligations in relation to health ${ }^{101}$ together with another list of six broad obligations of 'comparable priority'.102 By 2016, when it issued General Comment 22 on the right to sexual and reproductive health, CESCR had returned to a prima facie presumption, and included a more tailored but still ambitious list of obligations. ${ }^{103}$

Assessing why normative parameters for ESR, including TMB guidance regarding basic obligations, crumbled like sandcastles during COVID-19 undoubtedly calls for reconsidering the process for defining the relationship between core obligations and obligations subject to progressive realisation; the capacity and possibilities for state dialogue with supra-national bodies that would best enhance external accountability even in emergencies; and the content of obligations of 'international assistance and cooperation.' ${ }^{104}$

But most importantly, COVID-19 has shown that building durable ESR protections requires greater sensitivity to issues of political economy, which cannot be treated as a mere backdrop to formal normative scaffoldings. That is, COVID-19 struck a world where many if not most countries were shackled not just by the immediate measures adopted but by waves of neoliberal austerity and privatisation, including of health and social protection systems. The pandemic revealed starkly the eviscerating impacts on ESR of increasingly constraining macro-economic architectures that have hollowed out fiscal space and subjected many areas of health to 'decades of neglect and underinvestment' 105

Thus, it is unsurprising that even when health and other ESR obligations are assumed under international law and enshrined in constitutional law, there was a notable difference in the penalty imposed by de facto restrictions that

101 CESCR, 'General Comment No. 14 (2000) on the right to the highest attainable standard of health (article 12 of the international Covenant on Economic, Social and Cultural Rights)' (11 August 2000) E/C.12/200o/4, para. 43 (a-f).

102 Ibid., para. 44 (a-e).

103 CESCR, 'General Comment No. 22 on the Right to Sexual and Reproductive Health (Article 12 of the the international Covenant on Economic, Social and Cultural Rights)' (2 May 2016) E/C.12/2016/4.

104 See John Tobin, The Right to Health in International Law (Oxford 2012) 240; Alicia Ely Yamin, When Misfortune Becomes Injustice: Evolving Human Rights Struggles for Health and Social Equality (Stanford 2020) 143-144.

105 Dainius Pūras, 'Final report of the Special Rapporteur on the right of everyone to the enjoyment of the highest attainable standard of physical and mental health, Dainius Pūras' (16 July 2020) UN Doc A/75/163, para. 81 . 
were placed on such rights during COVID-19. In its January 2021 report, the Independent Panel on Pandemic Preparedness concluded: 'there was much more freedom to act and more choices were available in those places where a robust and resilient health system existed, where social and economic protections were solid, and where governments, scientists and citizens trusted each other to do their best'.106 The CoviD-19 crisis has taught us that, as Barbara Prainsack wrote, 'the most resilient societies are not those that have the best technologies or most obedient citizens. It is those that have solidaristic institutions', including adequate and equitably generated pooled financing to make ESR, including health-related rights, meaningful in practice. ${ }^{107}$

We might have learned the lesson earlier regarding the importance of democratic political economies, given that, as early as the mid- $19^{\text {th }}$ century, Rudolf Virchow's landmark 'Report of the Typhus Outbreak in Upper Silesia'108 included profound reflections on the disconnect between formal laws and institutions and state practice in Prussia. Nonetheless, Covid-19 has definitively demonstrated that international and comparative legal analysis must pay closer attention not just to the "grafting" of human rights into domestic constitutions ${ }^{109}$ - or onto global health law for that matter - but to strengthening democratic control over the social and material infrastructure necessary for attainment of ESR and their effective enjoyment in practice. Further, in the face of unpredictable health and other crises, mitigation of the adverse consequences of limitations on rights, as well as preservation of the attainment of rights, invariably calls for adequate institutional arrangements and processes to ensure that trade-offs are made in ways that are transparent, evidenceinformed, include diverse perspectives on conditions of rough background equality (including from marginalised populations) and are compatible with democratic norms in a plural society. ${ }^{110}$ Just as with physical sea walls to resist

\footnotetext{
106 Independent Panel for Pandemic Preparedness (n 31$) 39$.

107 Barbara Prainsack, 'Solidarity in Times of Pandemics' (2020) 7 Democratic Theory, 130.

108 Rex Taylor and Annelie Rieger, 'Medicine as Social Science: Rudolf Virchow on the Typhus Epidemic in Upper Silesia' (1985) 15 International Journal of Health Services, 547.

109 Roberto Gargarella, The Engine Room of the Constitution: Latin American Constitutionalism 1810-2010 (OUP 2013).

110 See, e.g., Ole F. Norheim, 'Ethical Priority Setting for Universal Health Coverage: Challenges in Deciding upon Fair Distribution of Health Services' (2016) 14 BMC Medicine, 75; wHO Consultative Group on Equity and Universal Health Coverage, 'Making Fair Choices on the Path to Universal Health Coverage' (2014). See also Norman Daniels, Just Health (CUP 2007); Alicia Ely Yamin and Tara Boghosian, 'Democracy and Health: Situating Health Rights within a Republic of Reasons' (2020) 19 Yale Journal of Health Policy, Law and Ethics, 87 .
} 
the damage of rising waves, the social infrastructure of democratically legitimate processes needs to be built ahead of time to withstand the ravages on ESR that a future storm akin to COVID-19 could wreak.

\section{4}

\section{Conclusions}

The lessons the world collectively takes from diverse responses to CoviD-19 will shape not just the nature of recovery and preparedness to face future pandemics and other inter-related disasters, such as imminent climate crises. The narrative we adopt will also determine the lasting legacy of this pandemic on the rule of law at both national and international levels, and faith in institutions of democratic and global governance. When navigating through the straits of Messina between Scylla and Charybdis, Odysseus chose to sail close to the Calabrian side where Scylla, the six-headed monster, took one soldier for each of its heads - as opposed to risking the entire ship in the whirlpool of Charybdis off the coast of Sicily. In hindsight, Odysseus made the better decision. Nonetheless, Covid-19 has revealed the dangers of deference to "wise leaders," as well as to technocratic expertise that cannot answer the most pressing questions about how to navigate uncertainty in plural societies.

In our globalised and inter-connected world today, there will not only be invariable trade-offs between securing public health and respecting civil, political, economic, social and cultural rights, including the right to health. In future pandemics as well as in climate change-related emergencies, there will likely be empirical uncertainty that eludes conventional scientific risk assessments and which carries different implications for the balance between precaution and proportionality across contexts of varied income levels and access to global public goods. In this article we have argued that there is a need for further theorisation of the balance between the principles of precaution and proportionality in global health law as well as derogations under human rights law.

However, we have also asserted that those trade-offs are most effectively and fairly made through democratically legitimate processes carried out consistent with substantive requirements under international and national law. In the absence of determinative scientific evidence, the regimes that govern global health law as well as international human rights law should reinforce democratic decision-making processes. Consistent with much constitutional law as well as international law, such processes should provide for explicit and transparent justifications of the reasonableness of policies, and deliberation that includes diverse perspectives, including of marginalised and disadvantaged groups, together with timely scrutiny by independent judiciaries. Further, 
COVID-19 has surfaced the need for more continuous and deeper dialogue with, and review by supra-national bodies, as a further check on abuse of power, as well as blind spots in policy-making.

COVID-19 has revealed that the ailing state of democratic institutions requires as much attention as formal 'pandemic preparedness'. In turn, we have seen that it is chimerical to attempt circumvent political pathologies with bureaucratic human rights operationalisation; positive international norms by themselves are quickly eroded in the waves of a global health emergency. The power - and legitimacy - of civil, political, economic, social and cultural rights comes from dynamic processes of interaction, and contestation, between actors framing social demands, and an array of national and supra-national institutions that can support those claims. When political and economic institutions are hollowed out, crises easily knock over the rights protections they are meant to shield.

In particular, this pandemic has exposed the effects of four decades of neoliberal, financialized capitalism on our current institutionalized social order and the conditions that sustain it, including predatory exploitation of workers, privatisation of health and pension systems, and the gendered dimensions of unremunerated care. As a result, there is a need for revisiting concepts of limitations of rights versus open-ended de facto restrictions even on "basic obligations". Protecting health, social protection, and other ESR during health emergencies, and in "normal times", requires making visible how the issues of rights attainment as well as definitions of rights restrictions are framed by structural conditions in national and global political economies. ${ }^{111}$ In short, COVID-19 has brought heightened awareness to the inextricable relationships between population health, economic and social well-being and human security, and in turn for the imperative of filling normative gaps in international legal regimes and strengthening democratic institutional arrangements and practices.

111 See Jededihah Britton-Purdy et al., 'Building a Law-and-Political-Economy Framework: Beyond the Twentieth-Century Synthesis' (2020) 129 Yale Law Journal, 1784. 